\title{
GASPAROV AND BAKHTIN
}

The essay here, back-translated from the Russian with some cuts and restorations for an Anglophone readership, first appeared in the journal Voprosy literatury [Questions of Literature] 2 (March-April 2006): 4-40. A reworked version appears as "In Honor of Mikhail Gasparov's Quarter-Century of Not Liking Bakhtin: Pro and Contra," in Poetics, Self, Place: Essays in Honor of Anna Lisa Crone. Catherine O'Neill, Nicole Boudreau, and Sarah Krive, eds. (Slavica, 2007): 26-49.

Mikhail Gasparov (1935-2005), Russia's great verse scholar, classical philologist, public intellectual, and for two decades Bakhtin's best known, most ardent detractor, managed to read the final draft before his untimely death in Moscow on November 7, 2005. In a personal communication in early October, very gravely ill, Gasparov graciously thanked me for "opening up new perspectives" on his disagreements with Bakhtin; confessed that "about New Historicism he had read little and without interest," that he was "ignorant of music" [v muzyke ya neuch] and thus intrigued by my paraphrase of Aleksandr Makhov (a Russian musicologist who has detected a sacred aspect to Bakhtin's use of the word polyphony), and that the alternation in approaches to philology between "the rational and the irrational" was probably dependent upon cyclical shifts in artistic taste. Picking up on a comment at the end of my essay he also apologized, in a way that could only make me cringe, for "being occupied with his own image-making."

The essay appeared in Voprosy literatury with this headnote:

"At the beginning of September, the Russian and English versions of this essay were sent to M. L. Gasparov. Already home and recovering from the medical treatment that turned out to be his last, Mikhail Leonovich was so kind as to read the text and respond to it at the beginning of October, making several small corrections concerning the ancient term 'serio-comical.' With his usual gallantry he only requested that I soften 'several of the eulogistic expressions about me' (which I did not), in this way letting me know that he was satisfied with how I had presented his position, and with the essay overall. Relying on this evidence, I dedicate the essay to his memory."

\section{TWENTY-FIVE YEARS LATER: GASPAROV ON BAKHTIN (2006)}

During the past quarter century, much has changed in the Bakhtin industry-but some things have remained the same. One of those unchanging things is Mikhail Gasparov's attitude toward Mikhail Bakhtin. 
Among American Slavists, Mikhail Leonovich enjoys a very high reputation: as a world-class scholar, an academic with an irrepressible sense of humor, a memoirist both astute and droll, and (although he would probably resist this designation) as a clear-thinking, commonsensical philosopher of the humanities. Out of the many scholars, critics, and cranks who have raised objections to Mikhail Bakhtin during his rediscovery and boom, M. L. has been Bakhtin's most principled opponent. By "principled" I mean: when Gasparov speaks out against an academic practice or a scholarly worldview, it is because he opposes to it a set of principles equally consistent, logical, value-laden and non-arbitrary. There has been a tendency among Bakhtin scholars to dismiss this criticism or to ignore it. I believe this is a mistake.

The present essay attempts to put the tension between Bakhtinians and Gasparovites into some context and intercultural perspective. Gasparov's opening statement appeared in 1979: "M. M. Bakhtin in Russian Culture of the $20^{\text {th }}$ century," in a Tartu School publication. ${ }^{1}$ His most recent update was a talk delivered in Moscow in November 2004: "The History of Literature as Creativity and as Research: The Case of Bakhtin."2 In the intervening quartercentury, variations on these two position papers are echoed in Gasparov's copious memoirs and writings on the humanities. It must be emphasized that the "dialogue" between these two scholars is of a special type. Since it was begun posthumously, one party (Bakhtin) has never been able to explain itself or answer back. Bakhtin's followers and disciples, often with intonations of impatience and protectiveness, have done so in his name. Only in the past decade has a team of highly-qualified intellectual historians (most of them in Moscow or in Manchester, England, and many associated with the Bakhtin Centre in Sheffield) begun to piece together what that name might have been

1 See M. L. Gasparov, "M. M. Bakhtin v russkoi kul'ture XX v." [1979] in M. L. Gasparov, Izbrannye trudy (Moscow, 1997), 2:494-96. For a history of the "Gasparovite" position on Bakhtin, see the commentary (507-10) to the reprint of Gasparov's 1979 essay in K. G. Isupov, ed., Mikhail Bakhtin: Pro et Contra (St. Petersburg: Izdatel'stvo Russkogo Khristianskogo Gumanitarnogo Instituta, 2002), 2:33-36. References to this essay in the text made to the Isupov edition. English translation by Ann Shukman: Mikhail Gasparov, "M. M. Bakhtin in Russian Culture of the Twentieth Century," repr. in Critical Essays on Mikhail Bakhtin, ed. Caryl Emerson (G. K. Hall, 1999), 83-85.

2 M. L. Gasparov, "Istoriia literatury kak tvorchestvo i issledovanie: Sluchai Bakhtina" [The History of literature as creativity and as research: the case of Bakhtin]. Materialy Mezhdunarodnoi nauchnoi konferentsii 10-11 noiabria 2004 goda, Russkaia literatura XX-XXI vekov: problemy teorii i metodologii izucheniia. Moskovskii gosudarstvennyi universitet im. M. V. Lomonosova, filologicheskii fakul'tet. The essay is reprinted in Word, Music, History. A Festschrift for Caryl Emerson (Stanford: Stanford Slavic Studies \#29-30, 2005), 1:23-31. 
for itself, that is, for Bakhtin and his close associates, in their own time. ${ }^{3}$ What is more, although the disagreement separating Bakhtin and Gasparov has become wider and wordier over the years, it has not necessarily become wiser. In the 1970s, Gasparov grouped Bakhtin together with the Petrograd Formalists as a "man of the Twenties" who shared the appeal as well as the weaknesses of other radical methodologies of that era. Overall, the tone of that early judgment was more insightful, measured and temperate than the recent complaints.

Gasparov has a potent defense. He would say that Bakhtinian truisms have so triumphed on the world market, and have caused so much more damage to humanities scholarship than anyone could have been predicted in 1979, that dissenting voices (of which his is the most famous) must be even more outspoken and vigilant. Gasparov is a methodological conservative and a bookish man, but with a high-profile publicistic side, unintimidated by theoretical vogue. To celebrate his seventieth birthday in 2005 , the journal Novoe literaturnoe obozrenie devoted a forum to his accomplishments in various genres (scholarly, aphoristic, memoiristic), praising Gasparov as an "academician-heretic." ${ }^{4}$ It was no surprise that this heretic-philologist of the old school was among the first to detect potential problems in Bakhtin as theorist and in the pattern of Bakhtin reception in the West. The brute surface of Bakhtin's ideas and images, grafted on to neo-Marxism, French neo-Freudianism, and the power-scenarios of Michel Foucault, had produced a philosophy of "transgressive words in a subversive body" that was enthusiastically embraced on European and American campuses in the politically radical 1960s and '70s. Bakhtin would have been astonished at this evolution of his message. Gasparov was appalled. There is some irony in the fact that the criticism Gasparov makes in his 1979 essay - his presumption

3 Among the most active scholars are Craig Brandist, Ken Hirschkop, David Shepherd and Galin Tihanov. For two excellent recent reconstructions in English of Bahktin's sources and contexts, see Craig Brandist, The Bakhtin Circle: Philosophy, Culture and Politics (London: Pluto Press, 2002), and Craig Brandist, David Shepherd \& Galin Tihanov, eds., The Bakhtin Circle: In the Master's Absence (Manchester UK: Manchester University Press, 2004).

4 “M. L. Gasparovu - 70 let," in Novoe literaturnoe obozrenie 73 (2005): 150-81, followed by a selection of eight essays "Vokrug Gasparova." [Henceforth, Novoe literaturnoe obozrenie will be abbreviated NLO.] Many tributes are anecdotal or testimonial, but among the most insightful is the "anti-jubilee offering" by three editors Aleksandr Dmitriev, Il'ia Kukulin, and Mariia Maiofis, "Zanimatel'nyi M. L. Gasparov: akademikeretik (“Antiiubileinoe prinoshenie" redaktsii "NLO")": 170-78. They point out that M. L.'s vibrant, eccentric voice had grown up inside the Soviet-era academy and had been rewarded by its institutions, but he was not entirely of that academy — and enjoyed being the outside jester to any pomp or pretension. 
that Bakhtin can be classified together with the radical Formalists in a single camp, with a collective set of methodological sins - fits into this Western perspective. Russian theory has routinely appealed to Western academics because it was sensed as exotic, dynamic, disruptive, "revolutionary."

Thus did Mikhail Leonovich take up his post as gadfly, speaking his truth to the tyrannies of critical fashion. Over the past quarter-century, the methodological divide between Bakhtinians and Gasparovites has become so well focused that it can now function as a threshold across which the costs and rewards of various approaches to knowledge in the humanities might be compared. What is philology? What is scholarship [or science: nauka]? What is the status of a surviving cultural trace (a book, fragment, legend, artifact) and are there reasonable limits to the stories that the critic can weave, in his own name, around this trace? What does it mean to "make contact with" another culture, especially one distant in time, space, language, and place? Can consciousness be captured by the word, and later retrieved from the word, in such a way that it effectively lives forever? Or are these claims merely one more chapter in the fanciful history of Russian philosophy's quest to abolish death? Answers to these questions vary widely. On balance, we can say that Bakhtin has served Gasparov well. Through a Bakhtinian lens, M. L. has been able to test and refine his own deeply-held convictions, not only regarding philology and scholarship but also in respect to ontology, creativity, morality, intimacy, addressivity [obrashchennost'], and - to apply an important distinction in Russian religious thought to the humanities - philological sobriety [trezvost'] versus philosophical pridefulness [prelest']. Although the humanities are not an exact science and our paradigms do not undergo scientific revolutions, most of us would agree that the terms and metaphors we employ can blunt and corrupt us. Is Gasparov correct in suggesting that we, as humanist scholars, have been blunted and led astray by Bakhtin's priorities?

My own feeling is that Mikhail Gasparov is a healthy corrective to Bakhtin Studies: to its moments of excess, hyperbole, and facile application. In an unexpected way, M. L. has even been Bakhtin's ally, warning us against the egocentrism natural to the creative and critical arts and urging a distance between ourselves and our objects of study. Both Bakhtin and Gasparov argue that "being outside looking in" is a more reliable starting point for knowledge than "being inside looking out." By making academic modesty his trademark, Gasparov reminds us of the more strictly service duties of literary scholarship - obligations alien to many Romantic-era and Postmodernist critics. But I could not ignore the fact that every Russian Bakhtin scholar whom I consulted on this matter, all of the highest calibre, 
expressed extreme disapproval of Gasparov's behavior vis-à-vis Bakhtin. Puzzled, I re-examined Gasparov for areas where Bakhtin might have been misrepresented. And indeed: there were identifiable moments.

This lack of acceptance began with Gasparov's secular and ironizing commitment to a "distrust toward the word" [nedoverie $k$ slovu]. ${ }^{5}$ Back in 1979, Gasparov had claimed that such distrust was necessary in order to "train us away from the spiritual egocentrism" so natural to humanistic inquiry and urge us toward a healthy objective ontology and from there to a sober philology. In Gasparov's view, the morality of philology lies precisely in its insistence on the virtues of objectivity and distance. For him, to respect distance means to realize that the written artifact I am now analyzing was not addressed to me, does not speak my language, is indifferent to my values, and should not be interpreted in light of my needs. In contrast, Bakhtin was less interested in the relationship between subject and artifact. His concern was always with the relationship between subjects. For him, distance is mandatory because "I" cannot know myself, only the Other can hope to know me. Thus Gasparov and Bakhtin both value "outsideness," but they put it to different purpose. In his objections to Bakhtin, Gasparov contributes to an ancient and venerable tradition. In his misrepresentations of Bakhtin, he is more original. This essay considers only two of Gasparov's objections and suggests possible rebuttals to them. The first objection is conceptual: Gasparov's non-acceptance of dialogue and its sister concept polyphony as useful or truthful tools for literary analysis. The second is methodological, and focuses on Bakhtin's love for the menippea-a preference that Gasparov takes as exemplary of Bakhtin's willingness to generalize a big theory out of rumors and shreds.

\section{Author and hero in academic activity, according to Gasparov: the distorting masks of dialogue}

Gasparov would reject outright the notion that his relationship with Bakhtin is a dialogue. He finds that idea as foolish and misleading as the kindred fantasy that fictional creatures can "converse" on their own initiative with

5 "Philology," Gasparov writes in his essay "Filologiia kak nravstvennost'," must "begin not with trust but with distrust of the word," for "it is natural to trust only the words of our own language." Philology is obliged to resist the temptation to reduce everything genuinely alien to something we can trust (that is, something we can talk to or converse with). M. L. Gasparov, "Filologiia kak nravstvennost'," the final entry in a forum on the Tasks of Philology in Literaturnoe obozrenie 10 (1979): 26-27, esp. 27. 
one another, or (as purportedly happens in polyphony) with their creatorauthor. All this talk of dialogue is delusionary, Gasparov would insist, because Bakhtin and his world are dead. Philology, which began as the study of ancient vanished cultures and languages, understands this fact and has adjusted its ambitions to the modest tasks of recuperation and transcription. A philologist does not refer to "conversation between the ages."

This part of Gasparov's argument has ancient credentials. The idea that dialogic form, and especially dialogue preserved in written form, is no more than a fraudulent reflection of life and thus cannot be revivified, finds its canonical expression at the end of the Phaedrus. In that Platonic dialogue, Socrates insists that words fixed in writing are dead, helpless to defend themselves before later audiences, and without any rights as regards their future addressees. Although these graphic representations "seem to talk to you as though they were intelligent," they will always resemble more an image painted on the wall than a true living conversation; "if you ask them anything about what they say, from a desire to be instructed, they go

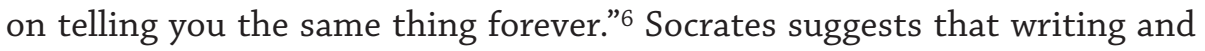
reading, characterized as they are by phonic silence and bodily absence, can only enfeeble or efface the genuine other. And if the other is flattened and made mute by the written word, then only the all-powerful, present-tense "I" of the currently alive reader is competent to move in and supply all voices for all sides of the dialogue.

Gasparov has been applying the acerbic skepticism of the Phaedrus to literary criticism for many years. Humanists mislead themselves about their "intimate relations" with their objects of study, he remarks. The fact that we work with the traces of deceased human consciousness, and not with inanimate objects or lower forms of life, should make us more cautious in our methods, not less. In a polemical jotting titled "Pseudo-philosophical note," Gasparov insists that "the zoologist relates more intimately to his frogs and worms that we do [to our human subjects]." This is wholly proper. Human consciousness does not lend itself to scrutiny like the tendon of an amphibian under a microscope. It requires more delicacy, more awe and respect. "The most everyday experience tells us that between myself and my most intimate friend there lies a massive block of mutual misunderstanding,"

6 "Phaedrus," in Plato: The Collected Dialogues, ed. Edith Hamilton and Huntingdon Cairns (Princeton: Princeton University Press, 1961), 521.

7 "Primechanie psevdofilosofskoe [iz diskussii na temu 'filosofiia filologii')" in M. Gasparov, Zapisi i vypiski (Moscow: Novoe literaturnoe obozrenie, 2000), 100-102, esp. 101. 
Gasparov writes; "after that can one even entertain the thought that we understand Pushkin? It is said that between a philologist and his object of study a dialogue takes place: what this really means is that one interlocutor is silent and the other devises answers to questions he himself has posed. On what grounds does he devise those answers? This is the question that must be answered, if the philologist is a person of science" (101).

This argument is reiterated, less patiently, in 2004. To see or hear "dialogue" and "otherness" on the printed page is simply an illusion. Or perhaps it is something worse: a "solipsistic, egocentric self-affirmation" that masquerades as two autonomous consciousnesses. Voices and words fixed in a text do not change or respond on their own. Rather it is we the readers who are growing, speaking, and evoling over time. Thus it only "seems to us that the text-interlocutor before us is changing," Gasparov insists. "The text is but a mirror reflecting our own changing face. Bakhtin gazes at his own 'I' in the mirror, and he imagines that it is Thou." Such egocentrism in a researcher - or in any reader - can only distort and repress surviving traces of real others, especially when attention is focused on the process [stanovlenie] rather than the product [proizvedenie] of creative activity. Gasparov's conclusion is that the sober procedure of philology, for all that it is accused of "necrophilia," in fact "respects the other more."

Such epistemological modesty is Gasparov's starting point and the source of his distinctive comic tone. Communication between people is far more difficult than we would like to believe. Bakhtin makes it appear easy and pleasant. The result can only be a profound misreading of where my self ends and another's self begins. On this score, Gasparov turns out to be a skeptical and shrewd thinker of the Tolstoyan school. ${ }^{8}$ We flatter ourselves when we find a "trace" and think it is talking to us, Gasparov argues. We lack the discipline even to listen to fully-embodied others in our very presence. As he remarked in his 1995 essay "Criticism as an End in Itself": "even when living people converse, we often hear not a dialogue but two chopped-up

8 Not coincidentally, such penetrating scholars of Tolstoy as Lydia Ginzburg (also a skeptic concerning Bakhtin's pan-dialogism) have long been making Gasparov's argument. It is Tolstoy, not Dostoevsky, who grasps fully the difficulty of socially contingent verbal communication, she insists; in Tolstoyan "conversations," more often awkward and failed than honest and eloquent, we recognize the dilemma of our expressive self. See Lydia Ginzburg, On Psychological Prose [1971 rev. 1977], trans. Judson Rosengrant (Princeton: Princeton University Press, 1991), 243: “To be sure, he [the contemporary human being] finds it more interesting to conceive of himself in Dostoevskian terms, since doing so allows him to focus his attention on his own self." 
monologues.... One could talk with a stone with equal success and imagine the stone's answers to one's questions. Few people talk to stones nowadays, at least not publicly, but every energetic person talks with Baudelaire or Racine precisely as with a stone..."9

Bakhtin might have countered this line of argument. Were he competent to conduct dialogue on Gasparov's terms (that is, if he were not bio-chemically dead), he would probably remark that his opponent, in his screed against dialogue, greatly inflates the power and single-voiced unity of any given living "I." My self is not an unconditioned absolute, and it is nowhere near as potent as Gasparov assumes. It cannot colonize others with impunity. Likewise, it cannot be reduced to a flat, reflected, bounded image (as Bakhtin excellently understood: for he, too, was an astute student of mirrors and a severe critic of all forms of duplicative sympathy). Mirrors are very poor metaphors. Voice belongs to another category of representation. No subject, however privileged in time and space, possesses a sufficiently high degree of power, integrity, or control to initiate a voice. Realizing a written dialogue, in Bakhtin's view, is not to assign it a voice but to respond to an already-hybrid voice. This voice-complex is already in the word. Coming across that word, I will always find more richness in it than its author-transcriber put there. Analogously, I will always find something different from the meaning that I alone could have invested in that word, had I myself uttered it. From this Bakhtinian perspective, the other is not only preserved by means of written embodiment but can even be enhanced, liberated, and returned to fuller consciousness. It is this conviction that motivates Bakhtin's choice of the novel - the world's first art form designed to be silently written and silently consumed - as the most freedom-bearing of all genres. Sergei Bocharov had this defense in mind when he offered his rebuttal to Gasparov in 1995: a past culture cannot be approached as a dead and foreign language. ${ }^{10}$

For all the energy put in on both sides, the distance between Gasparov and Bakhtin here cannot easily be bridged. Their core assumptions, unverifiable in themselves, are too different, touching on the most vital of our human intuitions about interpersonal relations. When literary scholars begin to talk in terms of dialogue, they become, for Gasparov, "philosophers" - and in the context of professional literary study, this is not a compliment. Consider the opening lines of Gasparov's 2004 "Case of Bakhtin":

$9 \quad$ M. L. Gasparov, "Kritika kak samotsel'," in NLO 6 (1993-94): 6-9. esp. 8-9.

10 Sergei Bocharov, "Sobytie bytiia: O Mikhaile Mikhailoviche Bakhtine," in Novyi mir 11 (1995): 211-21, esp. 212. 
M. M. Bakhtin was a philosopher. However, he is also considered a philologist - because two of his books are written about Dostoevsky and Rabelais. This has been the cause of many misunderstandings. In culture there are creative areas and research areas. Creativity complicates the picture of the world, introducing into it new values. Research simplifies the picture of the world, systematizing old values and putting them in order. Philosophy is a creative area, as is literature. But philology is a research area. Bakhtin should be valued highly as a creator - but there is no reason to attribute to him the achievements of a researcher. A philosopher in the role of a philologist remains a creative temperament, but manifests this trait in a highly unusual manner. He creates new literature as a philosopher creates a new system.

For this reason, Gasparov notes, "philosophers" (and Russian "philosophizing") are at special risk when they attempt to research the world. They enjoy constructing systems. But in their systems-building, they are too often motivated not by curiosity about the world but by anxiety, personal will, and — most dangerously, because most admirable in its own right — creativity. Whenever scholars are seized by a vision of themselves as creative centers, they become vulnerable to a dual seduction. First, they will take from the past only what satisfies their own need. And second, they will deny the reality of death - in the belief that they, from their present-tense position, can extract a "living word" from a past literary trace, permitting all of us to live forever.

Very early in his Bakhtin-watching activity, Gasparov must have feared that this rediscovered luminary on the Russian horizon would tempt the literary scholar to commit just such cognitive and ontological blasphemy. In urging readers to be creators or co-creators, Bakhtin (together with his contemporaries, the Petrograd Formalists) were promoting aggressively interventionist habits of reading. The very word "dialogue" invites these habits, Gasparov argues in his 1979 essay. When a reader enters into dialogue, he has a choice: either he "fits himself to the context of the thing, or fits the thing into his own context.... Dialogue is a struggle. Who will give in?" (34). In this struggle, it is always easier and more pleasant to fit the alien thing to us rather than to fit ourselves to it. Gasparov admits that the psychological reasons for doing so are very compelling. We have needs, whereas the thing (the inert text) does not.

To be sure, Gasparov's binary model - either I fit in to the text, or the text fits in to me-might strike some as a bullying set of options, a ktokogo relationship [who beats up on whom?] transferred to the plane of literary dynamics. In its very structure, it implies a vertical power relation of 
mastery for one side, submission for the other. For Gasparov, however, that imbalance is its virtue and an index of its honesty. Gasparov trusts traces of words more readily than he trusts their present-day carriers. Traces are disinterested. Always the professor and professional, Gasparov opposes any methodology that grants excessive interpretive rights to readers, for such methods cannot be standardized and cannot be taught. They are a trap. In the equalizing Bolshevik 1920s, Gasparov suggests, literary opportunism of this sort - making a work of art useful to my identity, my creativity, the wakefulness of my perception - was part of the anarchic and self-affirming spirit of the epoch. For very different reasons, this "present-tense self" was indulged by Formalists, Marxists, and Bakhtin in his neo-Idealist mode. In 1979, however, Gasparov was more generous than he was later to become, acknowledging that Bakhtin (unlike the posthumous industry that grew up around his word) was fully aware of this opportunism. ${ }^{11}$

What, then, is the mission of the philological self? Gasparov is a magnificent generator of definitions, aphorisms, and glossaries. His Zapisi $i$ vypiski [Notes and jottings] ${ }^{12}$ from 2000 contains an idiosyncratic thesaurus of concepts, quotations, and trenchant observations to rival Ambrose Bierce's Devil's Dictionary. But nowhere in his writings on the humanities does Gasparov define precisely and without irony what he considers to be appropriate motivation for literary study. The researcher's disinterested curiosity? Archeological investigation and recuperation for its own sake? The positivist dream of an answer to fill every blank, a history that "adds up"? A personal training course in modesty and discipline? If research is indeed destined to "simplify the world," generalization must occur at some level. What principles should govern it? Gasparov does not elaborate; the history of culture is a self-evident objective value.

11 As Gasparov wrote in 1979: Bakhtin's followers "made a research program out of his program for creativity. And these are things which are in principle opposed: the point of creativity is to transform an object, whereas the point of research is not to deform it... Just as Bakhtin called on his contemporaries to take only what they thought necessary for themselves, so now his new adherents take from his writings only what they think is necessary for them. But it is always best when this is done consciously, as Bakhtin himself did." Cited from Isupov, ed., 35; in Shukman translation (n. 1), p. 85, translation adjusted.

12 M. L. Gasparov, Zapisi i vypiski (Moscow: Novoe literaturnoe obozrenie, 2000). The book is assembled as a "thesaurus" containing several hundred pages of alphabetically arranged fragments and quotations (both correctly cited and hilariously distorted) "Ot A do Ia" [From A to Z], interspersed with parables, cameo memoirs, short critical essays, letters, and bits of verse. 
Gasparov would emphasize, however, that the suspicious stance of philologists toward philosophers is not because philologists believe that the verbal trace, the recorded or transcribed word, is incommunicative. The opposite is the case. Philologists revere the recuperated word. It carries precious information. For an historian of verse such as himself, most precious and authentic would be information contained in the form: patterns, rhythms, alliterations, rhymes, phonetic and semantic structures. These forms gain in sublimity and significance as they repeat, refract, and interrelate. For Gasparov, the life of the word is located in such dynamics - and this life is vital. But he would insist that no grounds exist for assuming that a word uttered or deployed by a person in the past can be resurrected or "spoken with," as if it were a sort of ghost or spore of consciousness. Nor can it give birth polyphonically to new persons, words, or forms. Gasparov suspects the Bakhtinians of making that mystical argument. His argument, therefore, is with the living.

In closing this section, we might note that the Gasparov-Bakhtin controversy has echoes in the American academy. On one side are the positivist, book- and print-bound scholars, "old historicists" who insist that the past belongs to the past and we must serve it on its own terms, through its intact masterpieces, because our predecessors did not produce their work with our values in mind (a position we might call "Gasparovism").13 On the other side are their contextual, postmodernist successors, most colorfully the "New Historicists," who insist that the past is available to us not only as a written text but also as a resonating field. This past is a source of information but also of wonder; when we enter this field, like Prospero on his isolated isle, we (or our obedient spirits) can activate it. The unique magic of literature is, as Stephen Greenblatt has claimed, its "uncanny ability of seeming to be written...' for us."'14

To the extent that Bakhtin and Greenblatt are both "anti-Gasparovites," they are a strange pair: of different generations, specializations, theoretical interests, passions, and temperaments. Gasparov, however, would see the similarities in a trice. He would find it fully correct that Greenblatt mentions Bakhtin as one of the "powerful intellectual encounters" influencing his

13 Since the past belongs to itself and not to us, there is no reason why it should want to enter into dialogue with us. See M. L. Gasparov, "Kritika kak samotsel'," in NLO 6 (1993-94): 6-9, esp. 8: "Nothing has been created or adapted for me in this world... every step of ours on this earth persuades us of that."

14 Stephen Greenblatt, "What Is the History of Literature?", Critical Inquiry 23.3 (Spring 1997): 460-481, esp. 481. 
work. ${ }^{15}$ The trajectories of these two academic stars in American intellectual culture are to some extent parallel. Greenblatt was also a cult figure during the 1970s and '80s. His imprecise but enticing New Historicism (like Bakhtin's imprecise and enticing "dialogism" and "carnival") was everywhere in the air. Both were credited with providing, in the wake of the dessicating rigors of a dominant impersonal structuralism, a new methodology for connecting context to text, a new model for relating parts to wholes, a new and more alive definition of the cultural artifact, and a sense of history liberated from strict linear causality. The scholarly style of each ingeniously combined eccentric micro-readings with bold mega-generalizations. What is more (and what would especially disturb Gasparov), each approach promises a fabulously creative role for the critic, albeit hidden beneath a self-effacing non-theoretical mask. For the mature and seasoned scholar this could be exciting; for the apprentice graduate student, disastrous.

Consider the confession that opens Greenblatt's 1988 essay launching the New Historicism: "I began with the desire to speak with the dead." ${ }^{16} \mathrm{He}$ is disarmingly honest about the status of these "dialogues" he wishes to pursue and the polyphonic "resonances" he hopes to detect - or to construct:

This desire is a familiar, if unvoiced, motive in literary studies, a motive organized, professionalized, buried beneath thick layers of bureaucratic decorum: literature professors are salaried, middle-class shamans. If I never believed that the dead could hear me, and if I knew that the dead could not speak, I was none the less certain that I could re-create a conversation with

15 In the 1960s and 70s, Russian theory was overwhelmingly viewed abroad as liberating and radicalizing. In the Introduction to his collected essays, Learning to Curse: Essays in Early Modern Culture (New York and London: Routledge, 1990), Stephen Greenblatt mentions several "powerful intellectual encounters" that helped shape his new approach to literary study: the Marxist Raymond Williams at Cambridge, Michel Foucault at Berkeley, but also the work of "Mikhail Bakhtin, Kenneth Burke, Michel de Certeau" (3). It would seem that early Russian formalists also played a role, with their combination of objective estrangement and sentimental concern for the intimately subjective. "I could not endure the compulsive estrangement of my life, as if it belonged to someone else," Greenblatt confesses, "but I could perhaps understand the uncanny otherness of my own voice.... I am committed to the project of making strange what has become familiar" (8).

16 Stephen Greenblatt, "The Circulation of Social Energy," Chapter One of Shakespearean Negotiations. The Circulation of Social Energy in Renaissance England (Berkeley CA: University of California Press, 1988), 1-20, esp. 1. Gasparov would agree absolutely with Greenblatt on the realness of the desire. But rather than justify one's method thereby, Gasparov would expect the scholar to resist the temptation. 
them. Even when I came to understand that in my most intense moments of straining to listen all I could hear was my own voice, even then I did not abandon my desire. It was true that I could hear only my own voice, but my own voice was the voice of the dead, for the dead had contrived to leave textual traces of themselves, and those traces make themselves heard in the voices of the living.

Greenblatt's confession can be read as an eloquent summary of Gasparov's complaints against the literary profession today, many of which he lays - justly or unjustly — at Bakhtin's door. These include the scholar as "shaman," whose deep psychological desire to practice magic somehow justifies his indulgence in it, his assumption that the dead can speak through his voice and with his voice. There is also the scholar as confessant, who fights against a fantasy but then, with an attractive display of candor, gives in to it, begging the reader's pardon. And mostly, there is the confusion of scholarly research with private needs and personal therapy (Renaissance self-fashioning is primarily the selffashioning of the critic). Circulation, negotiation, exchange, contingency, "resonance": all are inspired by the same heady possibility that every body can become an agent and leave a trace whose energies might be released by later critics. Gasparov would consider the "Case of Greenblatt" saturated with the neo-Romantic, quasi-mystical spirit of Bakhtinian readings. Precisely these aims and procedures of New Historicism are the profligate hopes of dialogue and (on the strictly literary plane) of polyphony.

Author and hero in academic activity, II:

polyphony, simultaneity, and sacred form

Critics of novelistic polyphony have long been bothered by its "faith-based" dynamic. How can a literary device lay claim to that moment in real life we call a "quickening of consciousness"? To be sure, polyphonic design serves a peculiar sort of creativity. Its endpoint is not a "creation" (a creature, an artifact) but other speaking personalities, that is, creatures which are designed in turn to create. Since they are verbal artifacts, what they create is more words, that is, the same material out of which they themselves were made. In order to ring true, conversation between such "creating creatures" must foster a sense of spontaneity and freedom. Students of more fixed literary forms have not been persuaded. But increasingly sober definitions of polyphony are being put forth — and if shown to reflect Bakhtin's intent, 
they might provide a more disciplined sense of "polyphonic form" that would pacify even the Gasparovite skeptics.

One pioneer in this regard has been Michael Holquist. In his explorations of Bakhtin and organicism, he advocates something more than a linear, alternating or oscillating model of dialogic and polyphonic relations. Holquist argues that Bakhtin's central theoretical concern, exemplified by his abiding interest in organic as opposed to mechanical unities, is simultaneity, the condition of continual feedback and "same-time-ness" among the varied phenomena necessary to life. ${ }^{17}$ Life-sustaining relations do not unfold or communicate "in a row" (such rows are merely our hobbled format for transcribing spoken dialogue) but rather co-exist on a field, the way voices and intonations co-exist within an uttered word, continually autoadjusting and self-monitoring. Visualized as the meshing of many responsive variables, polyphonic design is not a sequence but a ground of being. Like any successful organism, it must grow-but never autonomously, and never in directions wholly unconditioned.

This alertness to the constraints operable in effective polyphony has received unexpected support from the history of music criticism. In his 2005 essay "The 'music' of the word: from the history of a certain fiction," Aleksandr Makhov examines the lengthy, two-way tradition of terminological borrowings between music and verbal-art critics, coming to rest on Bakhtin's polyphony. ${ }^{18}$ Bakhtin has been criticized for his choice of this musical term, Makhov notes: it appears to confuse words with sounds and to rely parasitically on another artistic medium. But these objections are misguided. First, the term polyphony (like the concept of sonata form) originated in the teaching of Rhetoric and was borrowed by medieval music theorists from philological criticism. Bakhtin was not burglarizing the term but returning it to its original literary home. And second, polyphony has been isolated, wrongly but in most cases innocently by a secular readership, from the other two values that Bakhtin enters into the Dostoevsky book during the same discussion: simultaneity [odnovremennost' or "at-one-timeness"] and eternity [vechnost']. These two supplementary terms are in some tension

17 See, as an opening statement, Michael Holquist, Dialogism: Bakhtin and His World (London and New York: Routledge, 1990), 18-20, "The fundamental role of simultaneity," and also Michael Holquist, "Bakhtin and the Task of Philology: an Essay for Vadim," in In Other Words: Studies to Honor Vadim Liapunov, Blackwell, Finke, Perlina and Vernikov, eds. Indiana Slavic Studies vol. 11 (2000), 55-67, esp. 56.

18 Aleksandr Makhov, "'Muzyka' slova: iz istorii odnoi fiktsii," Voprosy literatury (SeptemberOctober 2005): 101-123, especially 119-23. 
with dialogue, which, for most of us, suggests something more this-worldly, linear, responsive, contingent, open-ended, a servant of freedom - at least to the extent that it welcomes an eruption of the unexpected along a temporal continuum. But neither simultaneity nor eternity is in any tension at all with medieval polyphonic music.

In its historical context, Makhov points out, sacred polyphony was a musical equivalent to allegory - that is, to the mystical simultaneity of Old-Testament events and their purported New Testament analogues. Such a semantic palimpsest does not generate or confirm the new: that is the noble task of dialogism in novels. Rather, its purpose is to enrich the reality of the old with new instantiations. Music (which tolerates repetition and duplication far more graciously than does the word) is ideally suited for this project. Verbal realizations of allegorical narrative - its "plot" - are inevitably limited by the fact that the words, to bear their message in an intelligible way, must occur one after the other. Only in musical polyphony can simultaneity become an uncompromised reality, a hetero-voicedness [raznoglasie] where the voices, no matter how abundant and particularized, never crowd one another out nor fail to contribute their part to the tonality of the whole. A tiny slice of time can communicate a manifold number of relationships.

Music, then, commands resources - or perhaps better, resonances beyond the semantic parameters of the spoken utterance. Musical polyphony creates not only a multi-layered sound-space but also a multi-layered meaning-space: powerfully fueled, compressed, contrapuntal, standing still while also moving toward a future already in place, inducing in us hope and faith. The paradigm that Makhov offers is Bach's Passions, where key sacred events are compacted and overlapped with no loss of suspense or dramatic power. Knowing what must happen and what has already happened, we are still on the edge of our seats. To be sure, this space is teleological and static. There is nothing unfinalizable or open-ended about it. But it would explain those radiant moments in Dostoevsky - unique to that writer in the modern period - where eternal questions are simultaneously posed, tested to the death, found to be helpless in altering the real course of events, yet nevertheless transcendently resolved: Raskolnikov at Sonia's knees in the Epilogue to Crime and Punishment, the Elder Zosima's advice to the desperate peasant woman who has lost her last remaining child; Alyosha Karamazov at Ilyushechka's funeral and his speech to the boys at the Stone.

We cannot know whether Bakhtin had in mind the potentials of sacred medieval polyphony. Musical genres do not play a large role in his thought 
and there is no genealogy of the idea in his notebooks. Most Bakhtin scholars assume his precedent to have been more strictly literary, dissonant, and modern ${ }^{19}$ - and indeed, one prong of the multi-voiced word might answer that intent. A hint of Makhov's sacred scenario, however, can be found in the final pages of the Dostoevsky book (in both its 1929 original and the 1963 revision):

At the level of his religious-utopian worldview Dostoevsky carries dialogue into eternity, conceiving of it as eternal co-rejoicing, co-admiration, concord. At the level of the novel, it is presented as the unfinalizability of dialogue, although originally as dialogue's bad infinity. ${ }^{20}$

Here we glimpse those two tiers of human existence that Makhov's vision of polyphony accommodates. The lower level of experience is dialogic: freely developing, unfinalized, open, unpredetermined, unstable — and thus, while radiant with personality, potentially tragic. The upper level is stable, true, eternal, "polyphonic" in a more fixed and sacred sense: the realm of joyful reconciliation.

If we take seriously Makhov's hypothesis, then, the phrase "polyphonic dialogue" is something of an oxymoron and deserves a sober reassessment. Dialogue in the sequential, linear, open-ended sense is certainly present in Dostoevsky's novels, and just as certainly leads to tragedy and pain. Such verbal dialogue must be laid out in a linear way. A novel, after all, is not a libretto. The conventional novel has no means for registering "ensemble talk" - the simultaneous singing or uttering of multiple messages and voice-lines with the expectation that the listener or reader will process the episode minute by minute as a single unified texture. But for that very reason, perhaps the concept of polyphony should not be fused with the dialogic idea, nor be defined merely as one extreme case of it. Dialogue

19 The most recent hypothesis on Bakhtin's source for polyphony, Brian Poole's, is incompatible with Makhov's. Poole has traced Bakhtin's source to German philosophical criticism, namely to the 19th-c. German novelist and critic Otto Ludwig, as cited in a 1923 study by the genre theorist Ernst Hirt. The relevant phrase polyphonischer dialog occurs in Ernst Hirt, Das Formgesetz der epischen, dramatischen und lyrischen Dichtung, although it is used there largely to explicate Shakespearean drama. See Brian Poole, "From phenomenology to dialogue: Max Scheler's phenomenological tradition and Mikhail Bakhtin's development from 'Toward a philosophy of the act' to his study of Dostoevsky," in Ken Hirschkop and David Shepherd, eds., Bakhtin and Cultural Theory, rev. and exp. 2nd edition (Manchester: Manchester University Press, 2001), 109-35, esp. 119; 131 n43.

20 Mikhail Bakhtin, Problems of Dostoevsky's Poetics, trans. Caryl Emerson (Minneapolis: University of Minnesota Press, 1984), 252. Translation adjusted. 
and polyphony might be two different, separate moves. If - as Makhov suggests - polyphony began as a dream of rhetoric, the dream that the world's apparent contradictions and heterogeneity could be expressed on one plane simultaneously, distinctly, yet still harmoniously, as a cosmic moment when the Music of the Spheres reinforces the Music of the Soul, then we have, in all its glorious fullness, the teaching of the Elder Zosima in pure transmusical form. And, we might add, whatever Bakhtin's intentions as a literary critic and whatever we wish to make of Bakhtin's professed Christianity, this medieval polyphonic vision is surely a crucial aspect of Dostoevsky's mature message. What else is his vision of Christian reconciliation: with one another, with reality, with the Truth? Dostoevsky loved that triune vision. But he found it terribly difficult to embody successfully - perhaps because words always fell short, and words were the sole tools of his trade.

What does Makhov's rehabilitation of Bakhtinian polyphony have to offer secular skeptics like Gasparov? Very little, to be sure, of religious inspiration. The Gasparovite critique does not consider spiritual consolation a proper concern of philological scholarship. (For the first time in 2004, Gasparov added to his Bakhtinophobe commentary some overt remarks about the Deity and the unfortunate, misplaced interest in Him that suffuses Bakhtin's literary philosophizing. ${ }^{21}$ ) But Makhov's commentary does address another vulnerable area in the literary wing of Bakhtin studies, and here Gasparov might find unexpected nourishment. Most critics of Bakhtin would agree that the customary interpretations of "dialogism" in Dostoevsky minimize or enfeeble the novelist's unitizing, transcendent message. Bakhtin is not especially good at accounting for Dostoevsky's epiphanies, spiritualized wholes, or intimations of Great Time. As an analytic tool, the "dialogized word" is far more successful with the concrete exchanges of Small Time. However, through Makhov's conceptual envelope for polyphony, we might accept Dostoevsky's great novels (and his own faith system also) as twotiered: dialogic on the secular plane and simultaneously sacred-polyphonic on a higher plane. ${ }^{22}$ The lower dialogic perspective is contingent, evolving,

21 "What Bakhtin wanted most of all was to talk about the transcendental, i. e. about God (about that God who is present as a Third above all human dialogues), but in general it is impossible to speak adequately about God in a human language, even independent of Soviet censorship conditions. About God one can only speak paradoxically."

22 It is of some interest for our enquiry into a more disciplined polyphony that Milan Kundera, a novelist with no love for Dostoevsky's themes but with a great love for (and training in) music, defines his own novelistic ideal, in the section on "Melody" in his "Improvisation in Homage to Stravinsky" from Testaments Betrayed, as contrapuntal 
tormented, continually open to doubt, "real." The upper polyphonic structure is as controlled, non-contingent, exquisitely balanced and spatially everpresent as a poem. And, of course, it is no less real. How could Mikhail Gasparov remain indifferent to the poet-musician who composed this complex fabric, or to a philosopher-critic who had glimpsed its design?

Author and hero in academic reality, III: menippea, Rabelais, and the disputed move from a cultural artifact to an artistic whole

Gasparov's 2004 "Case of Bakhtin" included several new charges against the defendant, in addition to that casual remark about God. Among the most damning pertains to the genre of menippea, "a new, previously unheard-of literature [so Gasparov tells us] whose program Bakhtin composed." Note he says composed [sochinil], not discovered or researched. As a classicist trained at the sources, Gasparov is troubled by Bakhtin's habit of selecting the most minuscule data-base of surviving fragments upon which to construct the most extravagant generalizations on literary history and the human condition. For how does Bakhtin procede? His first step is to apply a very broad genre definition to a very small body of documents. Gasparov cites the enormous range of "basic characteristics" that Bakhtin, in the new Chapter Four of his revised Dostoevsky book, attributes to menippean satire: fourteen traits overall, ranging from "the comic" to "the everyday" to "adventure" to "the fantastic" to "the quest," "the test," "the threshold," and "moral-psychological experimentation." 23 The presence of any one of these traits qualifies a work for the genre. What narrative anywhere in the world would be excluded? Since almost every conceivable plot can be made to fit some part of this

and polyphonic, somewhat as Makhov invokes the procedure here. Kundera's exemplary genre is the twelfth century polyphonic chant. What he loves about this ancient form is its "embrace of two melodies belonging to two different eras," one individually inspired, daring and transitory, the other sublimely archaic, clarifying, and eternal. See Milan Kundera, Testaments Betrayed: An Essay in Nine Parts, trans. from the French by Linda Ascher (New York: HarperCollins, 1995), 72. Earlier, in his study The Art of the Novel, Kundera had introduced concepts of novelistic counterpoint and polyphonic form, emphasizing how crucial to novelistic construction are the simultaneity and heterogeneity of multiply unfulfilled polyphonic lines: on this plane characters need not meet, converse, or affirm one another, because "the novel is the realm of play and of hypotheses” (his beloved example is Hermann Broch's Sleepwalkers, although Dostoevsky is also granted mastery: "He is a great thinker only as a novelist"). See Milan Kundera, The Art of the Novel, trans. Linda Ascher (New York: Grove Press, 1988), 73, 78.

Bakhtin, Problems of Dostoevsky's Poetics, 114-19. 
definition, for this "philosopher in the role of a philologist" a second step is indispensable: to select for analysis those texts, or fragments of texts, that "please Bakhtin personally, that he considers good and important."

Gasparov acknowledges the necessity of working with fragments. Literary history of the ancient period is a fragmentary science. However, this fact of the profession should impose greater caution and discipline on the philologist's imagination, not less. Thanks to Bakhtin - the exemplary creative philosopher falsely taken for a philologist - precisely the opposite has occurred with the menippea. In this distortion of our Greek and Latin heritage, Bakhtin lays bare his method and gives himself away. Why does he ignore the great canonized works of ancient literature, for example, the comedies of Aristophanes? Because, says Gasparov, the greatness and integrity of these finished works of art are felt by him as an impediment: "because Aristophanes is too politicized, too single-mindedly satirical, too non-chaotic, but ultimately because he exists - as a text, and not as a conjecture [domysel]." An integral, fixed text constructed by an individual genius imposes its own structures and its own truths, which humble its readers and restrict their free creative response. Since philosophers prefer to develop their own thoughts rather than analyze the objective data of the outside world, they naturally feel liberated by working with tiny fragments, which function not as aesthetic wholes but as isolated stimulants to their own fantasy and will.

Gasparov hints that such priorities also account for the strangely nonphilological qualities of Bakhtin's study of Rabelais. Where in that book is Rabelais as author, where is the integrity of his novels, why is there so much "cultural environment" - public squares and folk rituals - and so little attention to literary style or overarching Christian symbolism? If, as some have suggested, Bakhtin tends to evaluate the folk ritual of French peasant life in Rabelais's novels through the binary norms and taboos of Russian folk culture, it is because such intercultural, inter-epoch moves are easy and pleasant with so loose a methodology. Valuing the fragment over the whole, the energetic anecdote over the unitary vision, is common to Bakhtin's study of Dostoevsky (in part), of Rabelais (in greater part), and wholly of his remarks on the menippea. And the pseudo-scholarly results, Gasparov insists, are the fruits of ethical philosophizing, for which the most important thing "is not the system but the process."

Gasparov is troubled further by the fact that the "serio-comical" menippea as a genre was hardly known to European literary history - even to those who supposedly practiced it. "But this fact is often forgotten, because it is 
not historians but theorists of literature who use Bakhtin's ideas in their research." Bakhtin has name recognition; for the impatient theorist his word is authoritative, not the facts of literary history. He provides simple, satisfying categories that urge even apprentice scholars toward unwarranted intellectual boldness. Here Gasparov's charge resembles that mounted by American scholars against New Historicist methods. ${ }^{24}$ It also recalls reservations raised by American historians of Russian medieval culture against the mesmerizing binary paradigms popularized by the LotmanUspensky school. ${ }^{25}$

\section{In conclusion: \\ The paradoxical glories of the Russian critical tradition}

One paradox implicit in the present essay is that as personalities, Gasparov and Bakhtin share so much. Both are classicists, polyglots, bookworms, men of deep personal modesty, devoted more to library pursuits than to social causes, reluctant to put their private phobias or intimate struggles on public

24 These complaints begin with the priority given to "cultural fields" over individual artworks, and to the "environment" over the individual author. Bakhtinian turns of phrase (as reflected in that earliest bestselling volume of essays in English, The Dialogic Imagination) occur repeatedly in the anti-New Historicist critiques - invariably negatively inflected. Dialogue, loosely defined, is one of the master metaphors for a research method based on "circulation and exchange." The New Historicism considers the old historicism "monological," Edward Pechter remarks (1987); "Greenblatt prefers to see literary and cultural knowledge as parts of the same interpretive enterprise, as inter-animating each other" (293). But "the flow here is markedly one-way, from the cultural to the literary text, and the effect again is to privilege the cultural text as the stable and determining point of reference" (293). Earlier, that center was presumed to be the author. Now it is the field - a domain filled not with persons but with "power" and "discourse" (296). Fields and their "cultural texts" cannot be stable in the way that authored artworks are. They do not have determination and intention. Thus the stable center becomes the contemporary critic. Edward Pechter, "The New Historicism and Its Discontents: Politicizing Renaissance Drama," PMLA 102, no. 3 (May 1987): 292-303.

25 See the pioneering volume edited by Samuel H. Baron and Nancy Shields Kollmann, Religion and Culture in Early Modern Russia and Ukraine (De Kalb: Northern Illinois University Press, 1997), Editors' Introduction ("Religion and Cultural Studies in Russia, Then and Now," 3-16). For a tactful cautionary word on using cultural semioticians (identified loosely as "structuralists") as a source for historical thinking, see also the essay by David A. Frick, "Misrepresentations, Misunderstandings, and Silences: Problems of Seventeenth-century Ruthenian and Muscovite Cultural History" (149-68, esp. 152-54). 
display. A brilliant memoirist, Gasparov writing in that genre nevertheless cultivates a cool, wry, ironic persona; Bakhtin, as we know, expressed no interest in writing his memoirs at all. ${ }^{26}$ Both scholars avoid sentimental confession as a means of bonding with their readers. But they have come to exemplify two profoundly different academic worlds. What is the ultimate verdict on Gasparov's "Case of Bakhtin"?

That verdict is still out. Technically, the disagreement might be less over Bakhtin the thinker than over philosophy - or over the appropriate ways to think. For Gasparov, a discipline is known by its fruits. Philosophy is creative imagination, and philology (the path of the scholar) must be more recuperative, restorative, more formal and positivist. Bakhtin had another vision. His thought was speculative, ethical, of cosmic reach, and colored by German Romantic Idealism (in the Bolshevik 1920s, it was not Freud or Marx but Friedrich Schelling that he discussed lovingly for weeks on end with his close friends Lev Pumpianskii and Maria Yudina). ${ }^{27}$ The early German Idealists, of course, were no strangers to system nor to academic life; the modern humanities research university began in Jena and Berlin. But the fruits by which the Romantic philosophers are now known also cannot easily be fit into our academic disciplines. To the dedicated scholars now excavating the original contexts of Bakhtin's work, it seems that Bakhtin was neither a conventional philosopher nor a traditional philologist. He was an intermediate type of thinker, concerned - in the words of one sympathetic student of his thought - with "that new point of intersection between the problem-field of philosophy and of the humanities" at the turn of the twentieth century, an intersection that led to "the displacement, at the end of the 1910s, of any firmly-established concept of boundaries between science, philosophy, and religion." 28

Gasparov, too, admits of many types of philology and himself practices more than one type of criticism. In a brief paper delivered in 2002 entitled

See M. M. Bakhtin, Besedy s Duvakinym (Moscow: Soglasie, 2002), "Shestaia beseda," 295: "D: 'So you do not intend to write your reminiscences [vospominaniia]?' B: 'I absolutely do not intend to do so."

27 "I loved him [Schelling] very much and knew him through and through and from the bottom up," Bakhtin remarked. When Duvakin tried to prompt Bakhtin with Soviet-approved literary Romantics like Hoffmann, Bakhtin tactfully returned to the philosophical, idealizing writers "with a religious inclination," such as Novalis, who formed the core of his discussions (always on German texts in the original) with the Schellingist Maria Yudina. Besedy s Duvakinym, "Shestaia beseda," 271-273. See Irina Popova, "O granitsakh literaturovedeniia i filosofii v rabotakh M. M. Bakhtina," in Russkaia teoriia 1920-1930-e gody (Moscow: RGGU, 2004), 103-114, esp. 107. 
"How to Write a History of Literature," he gave his blessing to several different varieties of research: histories of forms, readerships, translations, reception..$^{29}$ Each type is valid, Gasparov writes, with one proviso: that it serve to "systematize our knowledge." And for those that do not? "As regards a history of literature undertaken not as a means for systematizing our knowledge but as a means of our spiritual self-affirmation - let there be as many such histories as one likes," he concludes (146). They live "from fad to fad." Such accounts will always be written. Born of the needs of the present, they will die with the present. They are not part of the philological record. Gasparov suggests that it is good practice for a scholar (and here we sense the imprint of his beloved Moscow formalist-folklorist B. I. Yarkho) to look even at the present with the eyes of the past - for "in fairytales, living water has its proper effect only after [we have encountered water that is] dead" (146).

Bakhtin was far less offended by histories that move "from fad to fad," because key for him was not a positivistic inventory of knowledge for its own sake, but the fact of movement itself. Bakhtin was also not particularly concerned, as a theorist, with the boundary between life and death. For that reason he tended to look at the past with the eyes of the present, or more precisely, through the potentials of the present. It was difficult, Bakhtin believed, to kill something off completely; not death but animation was the natural state of the world, and the spoken word was simply the best carrier of this principle. This essentially religious worldview probably cannot be packaged as philology. What appeals about Gasparov is his resolute and skeptical secularism; what dismays such thinkers about Bakhtin is his willingness to entertain the more spiritual side of the humanities. Gasparov's scholarly activity aims to save the text from careless or biased readers. Bakhtin, in contrast, sees the literary text from the very beginning as so gloriously multi-voiced, multi-centered and multifaceted that it is in no danger of being destroyed by any single reading or misreading. This conviction is central to Bakhtin's carnival spirit.

Over many years, Gasparov has cultivated a highly attractive, highly public persona, full of wit and the self-deprecating charm of understated performance. His memoirs and "jottings" are academic bestsellers. How this came to pass mystifies and delights his fans, even those not competent to appreciate his technical scholarly achievements in a dozen languages. 
"Mikhail Leonovich Gasparov endeavored throughout his entire life to eclipse himself behind his heroes and his texts," writes Yurii Leving in a special 2005 forum devoted to Gasparov's seventieth birthday, "but despite his exemplary scholarly modesty, he has not been successful: a style has emerged." 30 Bakhtin, in his time, was also a professor held in high esteem. But he was not a person of aphorisms or witticisms. All his wisdom passed through the texts he read, which he considered sufficient to ground his personality. With Bakhtin, so little is known of his doubts, raptures, and dead ends. Whereas Gasparov has been an active shaper of his own person and thus a participant in his own mythologization, Bakhtin had far less opportunity, and far less energy, for this task. They were heroes of different times. 